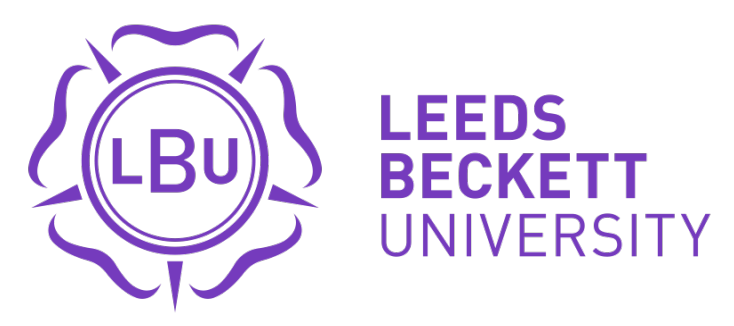

Citation:

Wan, A and Zulu, SL and Khosrowshahi, F (2019) Potential of Using BIM for Improving Hong Kong's Construction Industry. International Journal of 3-D Information Modeling, 7 (3). pp. 54-70. ISSN 2156-1710 DOI: https://doi.org/10.4018/IJ3DIM.2018070104

Link to Leeds Beckett Repository record:

https://eprints.leedsbeckett.ac.uk/id/eprint/5827/

Document Version:

Article (Published Version)

Copyright (C) 2018, IGI Global

The aim of the Leeds Beckett Repository is to provide open access to our research, as required by funder policies and permitted by publishers and copyright law.

The Leeds Beckett repository holds a wide range of publications, each of which has been checked for copyright and the relevant embargo period has been applied by the Research Services team.

We operate on a standard take-down policy. If you are the author or publisher of an output and you would like it removed from the repository, please contact us and we will investigate on a case-by-case basis.

Each thesis in the repository has been cleared where necessary by the author for third party copyright. If you would like a thesis to be removed from the repository or believe there is an issue with copyright, please contact us on openaccess@leedsbeckett.ac.uk and we will investigate on a case-by-case basis. 


\title{
Potential of Using BIM for Improving Hong Kong's Construction Industry
}

\author{
Allen Wan, Farspeed Group of Companies, Hong Kong, China \\ Sam Zulu, School of Built Environment \& Engineering, Leeds Beckett University, Leeds, UK \\ Fazard Khosrowshahi, College of Engineering \& Science, Victoria University, Footscray, Australia
}

\begin{abstract}
Given sizable capital projects in Hong Kong are using BIM from January 2018 on and site safety continues to be a concern for the local construction stakeholders. It is timely to investigate the potential of using BIM for construction safety. This research reveals the potential of using BIM for site safety is strong ( $85 \%$ supported), indicating Hong Kong should engage specific projects to test effectiveness of using BIM for safety, including implementation of safety management system and/ or process of risk assessment.
\end{abstract}

\section{KEYWORDS}

Architectural, BIM for Safety, Building Information Modelling, Engineering and Construction, Risk Assessment, Safety Management System

\section{INTRODUCTION}

In the past, the AEC sector considered the triangle of time, cost and quality as the key performance indicators (KPIs) to measure the success of projects. Over time, others have proposed to expand these KPIs. Nicholas (1989) identified that the multiple criteria for success are time, cost, quality and safety. Chua, Kog, and Loh (1999) considered that the critical success factors refer to the nature of the project and the company, and can also include safety consideration and market entry. In addition, Albert and Ada (2004) considered that the KPIs to reflect successful construction projects should cover eight different factors including quality specification, commercial value, environmental impact, user expectation, participant's satisfaction, health and safety performance, time, and cost. Gould and Joyce (2009) pointed out that in the US; workers expect site safety management in workplaces including construction sites. Construction is a relatively hazardous industry, requiring all stakeholders to be involved. More importantly, enforcement of the Occupational Safety and Health (OSH) Act in the US since 1970s sets the legal basis for construction companies on how to manage site safety.

The construction industry is a milestone sector of Hong Kong, representing 5.6\% of gross domestic product and 9.2\% workforce in 1999 (Construction Industry Review Committee Hong Kong Government, 2001). Unfortunately, and despite all effects, Hong Kong still has a relatively high number of accidents. During 2010-2014, accidents in the construction industry accounted for $25 \%$ of the total number of industrial accidents in Hong Kong. In fact, the construction industry accounted for $74 \%$ of all industry fatalities in Hong Kong over the same period (Labour Department Hong Kong Government, 2015). To “build a better 2030”, the Construction Industry Council in Hong Kong issued the challenge of the construction industry for manpower, productivity, safer, greener and 
collaboration including consideration of adopting Building Information Modelling (BIM) for safety McKinsey \& Company (2015) which is the focus of this paper.

\section{IMPROVING HONG KONG'S CONSTRUCTION SAFETY}

The European Union (2010) reported that the construction industry remains one of the most vulnerable sectors for accidents. There are many different tools to improve OSH including a combination of mandatory and voluntary measures. Ju (2014) listed the tools to include a mix of prescriptive, performance-based and general duties legislation or administrative measures. The OSH issues in Hong Kong are multi-folded and there are different approaches to manage site safety.

Traditionally, the approach was to impose legal controls following occurring of serious accidents, which is or often referred as "command and control" (Zhou, Irizarry, \& Li, 2013). More recently, use of risk assessment (RA) is becoming more widespread and evident in human safety, security, environmental protection, product quality, planning and change management processes. This led to the publication of an international standard, the ISO31000 series, with a cycle loop similar to BS8800 involving "mandate and commitment", "design of framework for managing risks", "implementation of risk management", "monitoring and review" and "continual improvement" (International Organization for Standardization, 2009). Many of Hong Kong's legislation or management practices refer to the process of risk management and RA, suggesting that combining RA and other safety initiatives will help improve OSH performances and lower accident injuries (European Union, 2010; Labour Department, 2014).

In parallel, different countries are adopting "safety management" as the strategy to reduce accidents. Safety management systems (SMS) have been adopted for the UK and Hong Kong as the way to manage and reduce site safety risks. Houssin and Coulibaly (2011) pointed out that the root cause of up to $60 \%$ of accidents was "design-related". Before ISO45001 - occupational health and safety management system, Hong Kong enacted Safety Management Regulation in 1997 which is now regarded as the key approach for managing construction safety in Hong Kong. Tam and Fung (1998) found the best safety management practices to reduce safety risks for Hong Kong's construction industries can include safety training, employment of direct work force, accident investigation and safety incentive scheme. Cheng, Ryan, and Kelly (2012) revealed three effective elements of SMS are safe inspection, safety training and safe work practices for Hong Kong.

However, the safety performance in Hong Kong's construction industry remains a concern and to "build a better 2030", the Construction Industry Council in Hong Kong issued the challenge of the construction industry for manpower, productivity, safer, greener and collaboration. In terms of safer construction environment, McKinsey \& Company (2015) recommended to initiatives to:

- Promote "design for safety" via consideration of the Construction Design Management regulation in UK and safety award for stakeholders;

- Promote safety ownership by extending the Pay for Safety scheme to include subcontractors and even frontline workers, and to highlight the different safety responsibilities among multi-tier contractors; and

- Adoption of new safety-improving new tools such as Building Information Modelling (BIM) safety from Finland or new construction methods from US into safety performance scheme.

It is beyond the scope of this paper to investigate all safety initiatives. The focus is to investigate the potential of using BIM for improving Hong Kong's construction safety. Since the approach to manage OSH in Hong Kong is mostly associated to RA and SMS, these will be targeted to gauge the potential of using BIM for construction safety. 


\section{POTENTIAL OF BIM FOR SITE SAFETY IN HONG KONG}

Similar to many other industries such as manufacturing and aerospace, the AEC is looking for ways to improve productivity, while keeping cost, time, constructability, environmental concern as well as site safety in check. There is evidence to indicate BIM can be a trend for the AEC sector as there are already BIM mandates from the USA, the UK, Singapore and Hong Kong.

In the UK, the term BIM became popular around 2003 when the Construction Industry Council UK (2013) used the term in the following way:

- B: Building as in Built environment, Built asset or Big data

- I: Information as in Innovation, Integration or Intelligence

- M: Model as in Modelling, Mining or Management

British Standards Institution (2013) identified BIM as a digital approach to manage the design, the construction or the operation of a building or infrastructure. Stanford University's Center for Integrated Facility Engineering recognized the BIM advantage to involve seven categories such as communication, facility performance, cost, schedule, project delivery, knowledge management as well as safety (Kam, Fischer, Rinella, Mak, \& Oldfield, 2014).

Royal Institute of British Architects (2012) considered BIM can be overlay to its "Plan of Work including 4D for time, 5D for cost and 6D for facility management. This study considers application of BIM to other dimensions such as safety which may be referred to as 7D. Selected examples are compliance checking (New York City, 2013), simulation of construction work process and site safety planning (Kiviniemi et al., 2011), worker safety training (Balfour Beatty Construction, 2015) and post construction and facility management (Mordue \& Finch, 2014). Existing literature indicates that common BIM for safety research are under groupings of planning and virtual simulation, sensor and warning device, and safety management (Wan, Platten, \& Briggs, 2013).

\section{RESEARCH APPROACH AND FOCUS GROUPS}

Leedy and Ormrod (2010) explained that common qualitative approaches are relevant for studying a real world and a complex subject. Moreover, Fellows and Liu (2008) validated the use of qualitative studies for management of technology and engineering in natural and social sciences. Selection of qualitative approach of focus group to investigate BIM for construction safety is documented by Wan (2017).

The academics in the 1980s began to adopt various approaches of focus groups for many fields including consumer-led preferences, market variables, scientific settings, public opinions, international disputes (Freeman, 2006; Kidd \& Parshall, 2000). Edmunds (1999) expanded the potential uses of focus groups to position a product or service, to test new concepts, to design and develop questionnaire, to evaluate advertising and to generate idea or brainstorming. Kidd and Parshall (2000) conducted the focus groups to examine the psychological, social and economic contexts of adopting engineering control and safety training to prevent occupational injuries.

Morgan (2012) introduced focus groups to follow a pattern; commonly the focus group meetings start with the facilitator outlining the topic and the purpose of the discussion to the respondents; the facilitator or the moderator will ensure the means of data collection are explained and carried out; then the facilitator will begin to lead participants through the prepared questions and discussions. Freeman (2006) pointed out that the objective of focus groups is to encourage self-discussion among members to capture the group dynamics, even allowing the members to question one another to seek clarification from group/individual statements. Morgan (1993) and Sim (1998) identified three advantages: the focus group not only allows each member to express his/her own view, he/she can also interact with others; in a non-threatening setting, there is little distinction between the management 
and frontline staff as everyone is allowed to express their ideas freely; and the views from different professions and trades can also be given equal consideration in the focus group.

The focus group meeting allows generation of data and learning as well as the degree of consensus on a topic from the targeted groups. This is important when different opinions exist between participants and stakeholders. The decision to implement BIM for safety is complicated as it involves various human and contract motivations as well as organization priorities. Although the focus group study is more an exploratory approach than a number-based one, with adequate statistical sampling the data can be generalized to a specific population. Since it may not be easy to find ways to talk about the implementation of BIM, the focus group is a useful tool for different stakeholders to discuss their opinions.

Beyea and Nicoll (2000a) outlined the potential disadvantages of using focus groups including inability for some to travel to the location, the potential for the moderator to influence those speaking incurring a bias, hesitation of participants to discuss their ideas, difficulty in assessing if participants withheld views or information, and time and resources demanding data analysis.

To maintain validity, a total of six different focus groups, representing different spectrum of construction stakeholders were conducted. More importantly, each member of focus groups or expert had relevant trade qualification; the working experience of respondents ensured each having adequate knowledge in construction, BIM and/or site safety. Given over $90 \%$ of the working population are Cantonese-speaking in Hong Kong, Cantonese was used in focus-groups meetings and voice recordings taken. In addition, notes were taken on the spot. All voice recordings were analysed by the researchers in order to translate them consistently into English and which was validated by third parties. Specific design of the focus groups including the trial, the objective, the sampling and the participants was explained by (S. C. Beyea \& Nicoll, 2000; Sim, 1998). All the transcripts were subject to content analysis providing another level of data for discussion.

In general, a content analysis is a tool adopting a fixed procedure to draw conclusion from the text. Typically it is done qualitatively so the content analysis can be referred to as a method for systematically describing the meaning of qualitative materials; in order words, after the content analysis, the text data can be classified into different categories (Schreier, 2012; Weber, 1990). More specifically, Grbich (2013) defined the content analysis as a tool to enable systematic categorising or coding in order to transfer large volume of text-based data to reveal the patterns and trends of words, their frequency, structures, contexts and other meaning of communication.

The logic for a category with higher frequency or being discussed by more participants is a direct reflection of the importance of this particular point of view; the assumption is that the comment with higher frequency count should carry more weight. Common key words and phrases during focus groups discussions are identified to allow categorisation and relevant summary made to reflect an overall picture of different focus groups (Chan et al., 2012). Instead of computer counting, humancounting can be adopted to provide the basis of discussion and analysis (Neuendorf, 2002). Using the literature framework from Rajendran and Clarke (2011), McGraw Hill Construction (2014), Construction Industry Council Hong Kong (2014), and Royal Institute of British Architects Enterprises Limited (2015), the wordings from participants were summarised first and then the meanings were categorised for discussion.

Content analysis has been utilised in the research of construction and other industries. Reutter and Ford (1996) conducted content analysis to study the mind-set roles of working nurses in Canada. In terms of the use of partnering in project management, Drexler and Larson (2000) carried out content analysis to study the effects and team-building elements of contractors and clients. Using content analysis for the construction sector, Teo and Loosemore (2001) revealed the concern of increasing solid waste. The study of important contributing domains for construction activities were looked at via content analysis (Yu, Shen, Kelly, \& Hunter, 2006). In Australia, content analysis was conducted to examine the impacts of waste levels for construction managers and workers (Lingard, Graham, \& Smithers, 2000). Scott, Hofmeister, Rogness, and Rogers (2010) used content analysis and focus 
groups to verify the implementation of a fatigue counter measure program. Chan et al (2012) did content analysis in China to look into how overseas construction managers deal with personal stress.

\section{CONSTRUCTION STAKEHOLDERS IN HONG KONG}

The AEC sector covers various stakeholders including the client, the designer, the engineer, the contractor and the manufacturer alike (Saunders et al., 2013). In order to investigate the potential of using BIM for safety, different parties such as the client (FMI, 2007) and the contractor (Ku \& Taiebat, 2011) should be consulted. This is why six different construction focus groups in Hong Kong were selected to reflect an industry wide representation and the potential usage of BIM for site safety is viewed through these construction stakeholders' perceptions, altitudes and views.

In theory, stakeholders within the AEC include any combination of:

1. Government and professional groups

2. Clients and consultants

3. Main Contractors, subcontractors and specialists

4. Unions, workers and industrial relations

Saunders et al. (2013) believe that the verification of a new concept or tool for the construction industry should involve different players such as the client, the designer, the engineer, the contractor, the manufacturer and other relevant parties. Figure 1 indicates the chosen focus groups representing the major construction stakeholders, covering clients (most with engineering or construction professional background), contractors (both civil and housing related), a specialist contractor (for lifting works), construction professionals (inspector grade) and safety professionals; arguably and as a pack, this represents the supply chain of the entire construction sector. Given that the focus of this project is the construction industry in Hong Kong; all these organizations are based in Hong Kong.

Each association from the particular focus group is a good representation of that trade, including the largest safety association, public works representation, contractors from the Housing Department where they construct buildings for about a third of Hong Kong's population, a major lifting specialist, a major civil contractor, and a well-known construction professional association. Details of the organizations and the focus groups meetings are documented by (Wan, 2017). Briefly, HKFOSHA is the largest representation of registered safety officers in Hong Kong, representing over 50\% of the registered safety personnel in Hong Kong. The Housing Department is the executive arm of the Hong Kong Housing Authority, which is a statutory body, mandated to establish almost all public housing programmes in Hong Kong and the list-building-new works-group 2 contractors are approved contractors to provide building works for the Housing Department. The major lifting specialist was the group companies of Farspeed Contractors Limited, which provides majority of transportation and lifting works for the elevator/escalator trade in Hong Kong. Involving in almost all urban planning and infrastructure development, Hong Kong's Works Departments includes Buildings Department, Lands Department, Lands Registry, Planning department, Architectural Services Department, Civil Engineering and Development Department, Drainage Services Department, Electrical and Mechanical Services Department, Water Supplies Department. The major civil contractor was Hsin Chong, a listed company in Hong Kong engaged in building, civil engineering, electrical and mechanical engineering, and railway projects. The construction professional association was Hong Kong Institution of Clerks of Works where members involve in superintending of construction works in Hong Kong. 


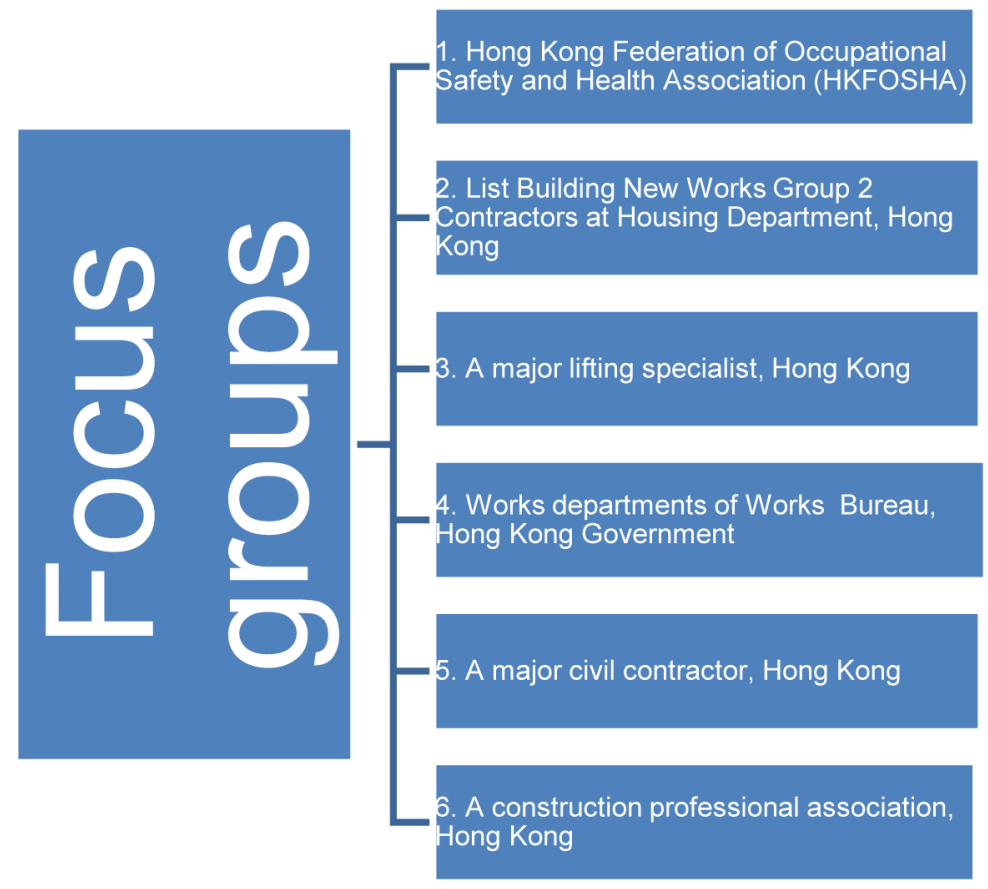

\section{ANALYSIS AND DISCUSSION}

In this paper, only the overall result and analysis is given. Discussion of each focus group result is reported in Wan (2017). It is clear that all six construction relevant focus groups supported BIM for safety. Since this result is based on the conclusions from focus groups in Hong Kong, the BIM for safety direction is most suitable for the construction industry in Hong Kong. In summary, two central research questions were addressed: one concerned about the potential of using BIM for safety with reasons of why and why not as well as which safety management system element(s) has the most BIM application potential; second was about the potential of using BIM for RA on lifting.

A total of 62 participants in the six different focus groups attended the data collection exercise, covering all the major AEC stakeholders, and all had a background closely related to Hong Kong's construction industry. Other than a few retirees, all were still active in the AEC sector; 95\% of the respondents were male. The overall average (from the six different focus groups) for supporting BIM for safety was $83 \%$, indicating a significant support level. The strongest support (100\%) came from the safety professional organization and the major civil contractor. It is understandable that safety personnel continue to seek ways to improve safety performance and they find this potential in BIM. The civil contractor was working for a multi-national railway client with extensive safety management requirements, which partly explained why they supported tools to improve safety further. The least BIM-for-safety supportive focus group was the lifting specialists where members were mostly operatives with little experience in SMSs, advanced technologies, and constructing lifting plans. Overall support for using BIM for safety is substantial as all groups had at least $75 \%$ or more support, except from the lifting specialist group (50\%).

It should be noted that within each focus group, there were different representations; for example, different safety associations from various construction organisations came to the HKFOSHA focus group meeting, different building contractors from different construction projects came to the Housing Department focus group meeting, different background of construction personnel came to 
Table 1. Summarised reasons for supporting BIM for safety by focus groups in Hong Kong

\begin{tabular}{|l|c|c|c|c|}
\hline \multicolumn{1}{|c|}{ Focus groups } & $\begin{array}{c}\text { Percentage of } \\
\text { supporting BIM for } \\
\text { safety }\end{array}$ & $\begin{array}{c}\text { Most frequent } \\
\text { reason }\end{array}$ & $\begin{array}{c}\mathbf{2}^{\text {nd }} \text { most frequent } \\
\text { reason }\end{array}$ & $\begin{array}{c}\mathbf{3}^{\text {rd }} \text { most frequent } \\
\text { reason }\end{array}$ \\
\hline HKFOSHA & $100 \%$ & Process & Communication & Accident \\
\hline $\begin{array}{l}\text { New Works } \\
\text { contractors of } \\
\text { Housing Department }\end{array}$ & $80 \%$ & $\begin{array}{c}\text { Simulate, visualise or } \\
\text { rehearsal }\end{array}$ & Training & Planning \\
\hline Lifting specialist & $50 \%$ & Assist lifting plan & - & Planning \\
\hline $\begin{array}{l}\text { Works departments at } \\
\text { Development Bureau }\end{array}$ & $93 \%$ & $\begin{array}{c}\text { Data provision or } \\
\text { coordination }\end{array}$ & $\begin{array}{c}\text { Visualisation or } \\
\text { communication }\end{array}$ & $\begin{array}{c}\text { Assist elements of } \\
\text { safety management } \\
\text { system }\end{array}$ \\
\hline $\begin{array}{l}\text { Major civil contractor } \\
\text { Vonstruction }\end{array}$ & $100 \%$ & Planning & $\begin{array}{c}\text { Visualisation or } \\
\text { communication }\end{array}$ & - \\
\hline professional group & $75 \%$ & $\begin{array}{c}\text { Display or explain } \\
\text { information }\end{array}$ & Visualisation & Disualisation or \\
Overall/Average & $83 \%$ & Planning & Data related \\
\hline
\end{tabular}

the Work Departments focus group meeting, different site staff came to the civil contractor and the lifting specialist focus group meeting, and different types of project staff came to the construction professional focus group meeting. This is significant because such combined batch of different construction stakeholders represents a heterogeneous mix of Hong Kong's construction industry and trade, which can form a credible basis to generalise the major findings.

This translates to two key points. One can argue that the construction industry in Hong Kong (covering public clients as well as building and civil contractors) is ready for some form of BIM implementation. This is not a surprise as there are BIM mandates globally already including in the US, the UK, Denmark, Singapore, South Korea, and Hong Kong, mostly for new sizable and public projects (Construction Industry Council Hong Kong, 2014). The findings in the focus groups are also consistent with the report that $92 \%$ believed the UK organizations will adopt BIM in three years (Royal Institute of British Architects Enterprises Limited, 2015). The findings of this research can be a starting point for a wider industry study (may be a more quantitative one) to investigate the potential for BIM implementation in Hong Kong. The argument is particularly strong for a BIM for safety follow-up study or a BIM implementation research with a focus in safety for Hong Kong's construction industry. The potential of the BIM for safety was measured in terms of the generic support of BIM for safety, which SMS element would be most suitable, and whether or not BIM can be effective for RA of lifting. However, these can be modified for the upcoming quantitative study. If these measuring potentials are to be adopted again, then the reasons and the concerns of the findings in this study can be the specified starting points for the next research.

The second key remark is that this "readiness" can be further applied to managing safety. This can be attributed to the fact that increasingly safety is part of the construction key performance indicators (Bealtham, Anumba, \& Thorpe, 2004). From the literature and in addition to clash detection, cost estimation, construction planning, and schedule control (Eastman, 2008), there are BIM adoptions for safety including the use of safety compliance checking (New York City, 2013), the simulation of construction work process, and site safety planning (Kiviniemi et al, 2011), for worker safety training (Balfour Beatty Construction), and for post construction and facility management (Mordue \& Finch, 2014). The results here indicate that the construction industry in Hong Kong is ready for using BIM 
to aid the safety management process. This is because to a large extent all six different construction stakeholders supported BIM for safety.

Then how can BIM contribute to safety? Table 1 lists the summarized reasons for using BIM for safety, namely visualisation or communication, planning and data accuracy. There may be overlaps among these reasons, but they are in line with the BIM literature (Kiviniemi et al., 2011; Miettinen \& Paavola, 2014; Ning \& London, 2010).

In addition to clients and designers, contractors will also consider BIM for safety as safety rests mostly with contractors; more importantly, safety risk in theory is the highest during the construction phrase where contractors have the most input. McGraw Hill Construction (2014) revealed that contractors believe top BIM benefits are errors and omissions reduction and collaboration with the client/designer. Looking at the major reasons for supporting BIM for safety, the researchers propose the key is for BIM to hold accurate and updated "safety data" as information or data is critical for managing safety.

Today, we live in an information packed world. Construction is also about using information and data for budgets, materials, labour, processes, programs and communication, involving clients, designers, contractors, site personnel and more. In the same way, safety is information dependent covering accident trends, training schedules, incident causes, control measures and others. The ability of BIM to integrate and display information is so significant that it will self-create more interests, if not already within the AEC sector (Anumba \& Wang, 2012). Jung and Joo (2011) argued that the recent BIM upgrades can push towards higher dimensions, for instance to 5D-cost, 6D-procurement, 7D-safety, and even beyond to nth dimensions. Assuming BIM is a better methodology for information, it is also suitable for safety too.

How information is recognized, inputted, stored, accessed, and retrieved can be a common concern. From Table 2, the consolidated concerns of BIM implementation of safety involved BIM or computer skills and knowledge, data update, quality or operation, and resources implications. The researchers argue that these can be grouped into competency and cost implication as BIM knowledge and data operation are closely related.

In the UK, the barriers for more BIM adoption are the lack of in-house expertise, the lack of training, no client demand, and cost (Royal Institute of British Architects Enterprises Limited, 2015). In Hong Kong, the concerns from contractors for BIM operation included "Will the contractor be able to obtain model for further development?" and "what are the risks of owning the data?" The findings of the focus group meetings are consistent with the literature.

Attempting to overcome the "competency" barrier, Hong Kong is calling for the development of BIM standards involving a project execution plan, BIM promotion to industry-wide stakeholders, and BIM training for both construction- and computer-based courses (Construction Industry Council Hong Kong, 2014). In the UK, there was a roadmap to deliver BIM skills to education and training courses (Farzad \& Yusuf, 2012). R. Sacks and Pikas (2013) went further in highlighting a BIM framework for construction-related university programmes. Therefore, in time and with better BIM products, standards, specifications, and experience, the BIM competency and the confidence of handling BIM data input, verification, modification, and security can be overcome. The cost implication is a difficult concern to mitigate. On the one hand, there is no standard measurement for "return on investment" yet. More importantly, the return can be positive rather than negative as McGraw Hill Construction (2014) found the positive gain from BIM can range from 10 to $25 \%$. If BIM implementation is mandated, then the BIM cost will be a part of compliance and simply a cost of doing a specific kind of "construction".

In addition to OSH legislation and economic incentive, a more recent approach to using occupational safety and health management system to improve safety performance has been mandated in Singapore and Hong Kong (Tam \& Fung, 1998; Teo \& Ling, 2006; Von Ahsen, 2014). There are different standards for SMS (British Standards Institution 2000; Standards Australia / Standards New 
Table 2. Summarised concerns about using BIM for safety by focus groups in Hong Kong

\begin{tabular}{|c|c|c|c|}
\hline Focus groups & $\begin{array}{l}\text { Most frequent concern } \\
\text { about using BIM for } \\
\text { safety }\end{array}$ & $2^{\text {nd }}$ most frequent concern & $3^{\text {rd }}$ most frequent concern \\
\hline HKFOSHA & BIM / computer skills & $\begin{array}{c}\text { Updating / operation of } \\
\text { BIM }\end{array}$ & - \\
\hline $\begin{array}{l}\text { New Works contractors of } \\
\text { Housing Department }\end{array}$ & Resources & Data updating or quality & Knowledge \\
\hline Lifting specialist & BIM skills & - & - \\
\hline $\begin{array}{l}\text { Works departments at } \\
\text { Development Bureau }\end{array}$ & Data accuracy & Resources implication & $\begin{array}{l}\text { For new projects or not for } \\
\text { minor task }\end{array}$ \\
\hline Major civil contractor & - & - & - \\
\hline $\begin{array}{l}\text { Construction professional } \\
\text { group }\end{array}$ & - & - & - \\
\hline Overall & $\begin{array}{c}\text { BIM or computer skills and } \\
\text { knowledge }\end{array}$ & $\begin{array}{c}\text { Data update, quality or } \\
\text { operation }\end{array}$ & Resources implication \\
\hline
\end{tabular}

Zealand, 2001). The SMS in Hong Kong has fourteen elements (Labour Department, 2002; Labour Department Hong Kong, 2000).

If BIM for safety is to be test-run before a full implementation, then what process or safety aspects should be conducted first? For countries, companies and sites adopting SMS, the question becomes 'Which SMS element(s) have the most BIM potential'. Table 3 indicates that the summarised BIM potential for SMS elements are the safety training, the job hazard analysis (often referred to as risk assessment), and the hazard control programme. The logical findings of this study can serve as the basis for a more industry representative future study also stands here; in order words, the concluding remarks of safety training, job hazard analysis, and hazard control programme can be the foundation of a more quantitative study for which SMS element(s) are most suitable for BIM-for-safety implementation in Hong Kong's construction industry.

For construction sites running pay-for-safety schemes in Hong Kong, safety training can be profitable (Choi, Chan, \& Chan, 2012). The effectiveness of safety training can be hard to gauge. Sacks, Perlman, and Barak (2013) found that virtual reality (which is BIM relevant) in construction safety training is more effective. It is reasonable to assume that once OSH risks are identified, it is vital to implement control measures to mitigate these risks; this explains why participants selected "hazard control program" as one of the most suitable SMS elements for BIM adoption. Therefore, the commencement of the next BIM study on SMS can be at elements of safety training, job hazard analysis, and the hazard control programme.

\section{POTENTIAL OF USING BIM FOR RISK ASSESSMENT}

Those involved in managing OSH often discuss hazard identification and RA before deciding what control measures should be carried out (International Labour Office - Occupational Safety and Health Branch, 2014). Construction or installation of a project involves many different processes and trades. The researchers selected a common, yet hazardous operation - lifting as the example in focus group meetings. On a global scale, there was a significant number of serious lifting accidents in the US (Shepherd, Kahler, \& Cross, 2000), in the Netherlands (Aneziris et al., 2008), in Korea (Shin, 2015), in Japan, and Hong Kong (Tam \& Fung, 2011).

According to Table 4, there was strong overall support (85\%) for using BIM to do the RA with the least support from the Works Departments focus group (50\%). Not counting the Works Departments 
Table 3. Summarised SMS elements with the most BIM potential for the construction industry in Hong Kong

\begin{tabular}{|l|c|c|c|}
\hline \multicolumn{1}{|c|}{ Focus groups } & $\begin{array}{c}\text { Most frequent SMS } \\
\text { elements }\end{array}$ & $\begin{array}{c}\mathbf{2}^{\text {nd }} \text { most frequent SMS } \\
\text { elements }\end{array}$ & $\begin{array}{c}\mathbf{3}^{\text {rd }} \text { most frequent SMS } \\
\text { elements }\end{array}$ \\
\hline HKFOSHA & Job hazard analysis & Safety training & Hazard control programme \\
\hline $\begin{array}{l}\text { New Works contractors of } \\
\text { Housing Department }\end{array}$ & - & - & - \\
\hline Lifting specialist & - & Job hazard analysis & $\begin{array}{c}\text { Accident / incident } \\
\text { investigation }\end{array}$ \\
\hline $\begin{array}{l}\text { Works departments at } \\
\text { Development Bureau }\end{array}$ & Safety training & Safety training & Job hazard analysis \\
\hline Major civil contractor & Hazard control programme & Half of all elements & - \\
\hline $\begin{array}{l}\text { Construction professional } \\
\text { group }\end{array}$ & Safety training & Job hazard analysis & Hazard control programme \\
\hline Overall & Safety training & & \\
\hline
\end{tabular}

group, the support was at least $78 \%$ with three different groups scoring $100 \%$. One explanation is that those working at Works Departments are civil servants, likely to be involved in design or coordination rather than construction activities. Traditionally contractors are perceived to have total safety responsibilities as well as the duty to conduct RA. The cited reasons for supporting BIM for RA were communication, data accuracy, and ability to expand.

The "ability to expand" can be the vital reason why many are looking to become involved in BIM as in theory there is no boundary for BIM or information. Smith (2009) insisted information and data are important throughout building design and construction, and are used by different parties including the client, the architect, the consultant, the engineer, and the contractor. Jung and Joo (2011) argued this BIM advantage can provide a multi-dimensional platform for $5 \mathrm{D}, 6 \mathrm{D}$ to nth dimensions construction process.

In practice, there is still concern about BIM implementation. In Table 5, the focus groups identified major concerns to be data accuracy, resources implication, and site conditions. Again, the findings of "what are the reasons and what are the concerns of using BIM to do risk assessment" can be the basis for another major "quantitative" study on whether or not BIM can be effective for RA for lifting and other relevant construction process.

Lifting operations are common construction tasks at site, which may require many lifting visualisations, leading to possible cost implications and implementation bottlenecks. Another valid concern was related to data accuracy as site conditions change quickly and existing BIM may not contain either weather or human factors. The concerns about the legal status of BIM, data security, and provision of hardcopy of RA were also mentioned.

Firstly, these are operation issues involving objects, processes and the link to visualisation using BIM software. Currently, about $60 \%$ of BIM objects come from in-house creation, project addition, manufacturer or Computer Aid Design (CAD) package (Royal Institute of British Architects Enterprises Limited, 2015). Once the object databases are readily available within the industry, trade or association, the visualisations of these processes are an easy addition to normal computer usage. There are different BIM training initiatives at various levels in Hong Kong and the UK. Whether or not BIM is implemented at sites, there will always be changes at sites. When the BIM competency becomes a norm, it will be a standard practice for the construction industry to adopt BIM in the same way as the CAD evolved.

Different organizations are in the process of setting up standardized BIMs; examples are the specification of Construction Operation Building information exchange (Nisbet, 2012), the common data environment (British Standards Institution, 2013), the security arrangement (British 
Standards Institution, 2015), and regular BIM practices (Construction Industry Council Hong Kong, 2014). More importantly, the verification of changing site conditions can be enhanced by mobile technologies (Anumba \& Wang, 2012) with laser scanning and live camera/sensor setup (McGraw Hill Construction, 2014). With time, these advance and other cloud systems will assist in resolving the data concern for BIM.

The researchers regard the cost implication argument of BIM is similar to the argument of spending more to clean up our environment. The RA process is a part of the SMS, impacting safety performance. Assuming BIM offers an overall safety improvement, then is it justified for the AEC sector to spend that extra amount to save life? Interestingly, one of latest BIM surveys revealed that BIM makes a positive return on investment (including safety consideration) (McGraw Hill Construction, 2014).

In the literature, Guo, Li, Chan, and Skitmore (2012) confirmed that BIM is useful for lifting. There are other examples as Kim and Teizer (2014) reported the use of BIM for scaffolding as well as the integration with safety management (Benjaoran \& Bhokha, 2010). In general, the lifting visualisation can add benefits to the process of RA in lifting; this is because the visualisation enhances communication among project personnel and identification of relevant hazards. Moreover, the data from the lifting visualisation can be used to form a lifting plan, checklist or even a lifting game for counter checking or practice. In theory the BIM-data setup can be a part of the project submission or process permit application.

In summary, there is obvious support for using BIM for safety in the construction industry in Hong Kong. From the six different construction focus groups, the support was $83 \%$ to adopt BIM for safety and $85 \%$ to use BIM for RA in lifting. Although the investigation was limited in size, the coverage was extensive for the construction stakeholders, totaling six different groups and 62 active construction personnel. This level of support is consistent with other BIM surveys and reports.

While the main support of using BIM for safety included visualisation or communication, planning and data quality, the key concerns were BIM or computer skill and knowledge, data updating, and resources implication. Both support and limitation were relevant and in line with the current literature. The reported BIM advantages are relevant for communication and visualisation of process sequence, which can be useful for coordination, virtual rehearsal, and training. These outweigh the

Table 4. Summarised reasons for using BIM for risk assessment by focus groups in Hong Kong

\begin{tabular}{|l|c|c|c|c|}
\hline \multicolumn{1}{|c|}{ Focus groups } & $\begin{array}{c}\text { Percentage of } \\
\text { supporting BIM for } \\
\text { risk assessment }\end{array}$ & $\begin{array}{c}\text { Most frequent } \\
\text { reason }\end{array}$ & $\begin{array}{c}\mathbf{2}^{\text {nd }} \text { most frequent } \\
\text { reason }\end{array}$ & $\begin{array}{c}\mathbf{3}^{\text {rd }} \text { most frequent } \\
\text { reason }\end{array}$ \\
\hline HKFOSHA & $100 \%$ & $\begin{array}{c}\text { Complicated lifting } \\
\text { task }\end{array}$ & $\begin{array}{c}\text { Checking or updating } \\
\text { lifting }\end{array}$ & Planning \\
\hline $\begin{array}{l}\text { New Works } \\
\text { contractors of } \\
\text { Housing Department }\end{array}$ & $100 \%$ & $\begin{array}{c}\text { Facilitate risk } \\
\text { management }\end{array}$ & $\begin{array}{c}\text { Training or } \\
\text { communication }\end{array}$ \\
\hline Lifting specialist & $100 \%$ & Communication & Data accuracy & - \\
\hline $\begin{array}{l}\text { Works departments at } \\
\text { Development Bureau }\end{array}$ & $50 \%$ & Ability to expand & $\begin{array}{c}\text { Presentation or } \\
\text { visualisation }\end{array}$ & - \\
\hline $\begin{array}{l}\text { Major civil contractor } \\
\text { Construction } \\
\text { professional group }\end{array}$ & $80 \%$ & $\begin{array}{c}\text { Visualisation or } \\
\text { communication }\end{array}$ & $\begin{array}{c}\text { Apply to large project } \\
\text { or ability to expand }\end{array}$ & - \\
\hline \begin{tabular}{l} 
Overall/Average \\
\hline
\end{tabular} & $78 \%$ & Provide data & Communication & Ability to expand \\
\hline
\end{tabular}


Table 5. Summarised concerns about using BIM for risk assessment by focus groups in Hong Kong

\begin{tabular}{|c|c|c|c|}
\hline Focus groups & $\begin{array}{l}\text { Most frequent concern } \\
\text { about using BIM for risk } \\
\text { assessment }\end{array}$ & $\begin{array}{l}\text { 2nd most frequent } \\
\text { concern }\end{array}$ & $3^{\text {rd }}$ most frequent \\
\hline HKFOSHA & Data details & Time or cost implication & Updating \\
\hline $\begin{array}{l}\text { New Works contractors of } \\
\text { Housing Department }\end{array}$ & Scope of quality of data & Cost implication & Site changes \\
\hline Lifting specialist & Data accuracy & - & - \\
\hline $\begin{array}{l}\text { Works departments at } \\
\text { Development Bureau }\end{array}$ & $\begin{array}{c}\text { Available of basic BIM } \\
\text { or data }\end{array}$ & BIM competence & - \\
\hline Major civil contractor & $\begin{array}{l}\text { Reflection of actual } \\
\text { conditions }\end{array}$ & Resources implication & - \\
\hline $\begin{array}{l}\text { Construction professional } \\
\text { group }\end{array}$ & Data dependent & $\begin{array}{l}\text { More research and } \\
\text { development }\end{array}$ & \\
\hline Overall & Data dependent & Resources implication & Site conditions \\
\hline
\end{tabular}

BIM limitations. With time, the concerns will be resolved by higher BIM competency and wider availability of BIM databases.

If BIM was to be added to the SMS setup in Hong Kong, the focus groups considered the most suitable elements would be safety training, job hazard analysis, and hazard control program.

Similar to the finding of BIM for safety, there is clear support (85\%) for using BIM to do lifting RA. The reasoning and limitation for using BIM for lifting RA followed the similar pattern in "BIM for safety". The major reasons for using BIM to do RA were communication, data accuracy, and ability to expand. On the other hand, the concerns of BIM implementation involved data, resources implication, and site conditions. These answers to the question of BIM implementation are consistent with the existing BIM understanding.

The key potential of BIM for safety was investigated and analysed in terms of six different construction stakeholders in Hong Kong and findings reported above. It is significant to point out that while the qualitative nature of this study may limit the findings to be generalised, the evidence-based conclusion is vital for the starting point of a wider industry study (may be a quantitative nature) to investigate the potential for BIM implementation in Hong Kong. The argument is particularly strong for a BIM for safety follow-up study, for which SMS element(s) is the most suitable and for whether or not BIM is useful for conducting RA of lifting.

\section{CONCLUSION}

It was revealed that qualitative approaches (with triangulation) are suitable for the research of construction management. Thus, the researchers regard that the data collection via focus groups were viable methods for collecting evidence to reflect the potential of BIM for safety.

The AEC sector is a multi-discipline one. In order to reflect this, a total of six different construction based stakeholders was targeted ranging from safety professionals, building contractors, public clients, a major civil contractor, lifting specialists and construction professionals. The focus groups were all based in Hong Kong and all directly related to the construction sector. From the six focus group meetings, there were 62 participants, mostly males and still active in the construction trade.

Studies indicate the most common strategy of managing OSH often involves a combination of SMS and/or RA. Therefore, the potential of using BIM for safety was reflected under these two elements. The average overall generic support of using BIM for safety was $83 \%$, indicating a 
significant level of support for using BIM for safety in Hong Kong's construction industry; other than the lifting specialist group, all had at least 75\% support. In Hong Kong, the 14-elements SMS is a legal mandate for sizable construction companies and sites. The most suitable SMS elements for BIM implementation identified were the safety training, the job hazard analysis (RA related), and the hazard control programme.

The second factor to gauge the BIM for safety potential was related to BIM's ability to assist RAs. The focus was on the RA for lifting. The overall support for using BIM to do RA was at $85 \%$, suggesting a substantial level for using BIM to conduct RA of lifting.

To conclude, the potential of using BIM for the construction safety in Hong Kong is high; this is based on the figures from the generic support of using BIM for safety (83\%) and the support of using BIM for RA of lifting ( $85 \%)$ as well as the strong support from the experts. 


\section{REFERENCES}

Albert, P. C. C., \& Ada, P. L. C. (2004). Key performance indicators for measuring construction success. Benchmarking: An International Journal, 11(2), 203-221. doi:10.1108/14635770410532624

Aneziris, O., Papazoglou, I., Mud, M., Damen, M., Kuiper, J., Baksteen, H., \& Oh, J. et al. (2008). Towards risk assessment for crane activities. Safety Science, 46(6), 872-884. doi:10.1016/j.ssci.2007.11.012

Anumba, C. J., \& Wang, X. (2012). Mobile and Pervasive Computing in Construction. John Wiley \& Sons. doi:10.1002/9781118422281

Balfour Beatty Construction. (2015). BIM for Zero Harm.

Bealtham, S., Anumba, C. J., \& Thorpe, T. (2004). KPIs: A critical appraisal of their use in construction. Benchmarking: An International Journal, 11(1), 93-117. doi:10.1108/14635770410520320

Benjaoran, V., \& Bhokha, S. (2010). An integrated safety management with construction management using 4D CAD model. Safety Science, 48(3), 395-403. doi:10.1016/j.ssci.2009.09.009

Beyea, S. C., \& Nicoll, L. H. (2000). Learn more using focus groups. AORN Journal, 71(4), 897,899-897,900. doi:10.1016/S0001-2092(06)62276-X

British Standards Institution. (2000). Occupational health and safety management systems - guidelines for the implementation of OHSAS 18001.

British Standards Institution. (2013). PAS 1192-2: Specification for information management for the capital/ delivery phase of construction projects using building information modelling.

British Standards Institution. (2015). PAS 1192-5: Specification for security-minded building information modelling, digital built environments and smart asset management.

Chan, , Leung, M., \& Yu, S. S. W. (2012). Managing the stress of Hong Kong expatriate construction professionals in mainland China: Focus group study exploring individual coping strategies and organizational support (Author abstract). Journal of Construction Engineering and Management, 138(10), 1150-1160. doi:10.1061/(ASCE) CO.1943-7862.0000533

Cheng, R., Ryan, N., \& Kelly, S. (2012). Exploring the perceived influence of safety management practices on project performance in the construction industry. Safety Science, 50(2), 363-369. doi:10.1016/j.ssci.2011.09.016

Choi, T. N. Y., Chan, D. W. M., \& Chan, A. P. C. (2012). Potential difficulties in applying the Pay for Safety Scheme (PFSS) in construction projects. Accident; Analysis and Prevention, 48, 145-155. doi:10.1016/j. aap.2011.04.015 PMID:22664678

Chua, D. K. H., Kog, Y. C., \& Loh, P. K. (1999). Critical success factors for different project objectives. Journal of Construction Engineering and Management, 125(3), 142-150. doi:10.1061/(ASCE)0733-9364(1999)125:3(142)

Construction Industry Council Hong Kong. (2014). Roadmap for BIM strategic implementation in Hong Kong's Construction Industry.

Construction Industry Council UK. (2013). Growth through BIM.

Construction Industry Review Committee Hong Kong Government. (2001). Construction for Excellence Report of Construction Industry Review Committee.

Drexler, J. A., \& Larson, E. W. (2000). Partnering: Why project owner-contractor relationships change (Statistical Data Included). Journal of Construction Engineering and Management, 126(4), 293. doi:10.1061/(ASCE)07339364(2000)126:4(293)

Eastman, C., Teicholz, P., Sacks, R., \& Liston, K. (2008). BIM handbook: a guide to building information modeling for owners, managers, designers, engineers, and contractors. Hoboken, NJ: John Wiley \& Sons.

Edmunds, H. (1999). The Focus group research handbook. Lincolnwood, Ill.: NTC Business Books. 
European Union. (2010). Health and safety at work in Europe (1999-2007) A statistical portrait. Retrieved from http://ec.europa.eu/eurostat/documents/3217494/5718905/KS-31-09-290-EN.PDF/88eef9f7-c229-40deb1cd-43126bc4a946

Farzad, K., \& Yusuf, A. (2012). Roadmap for implementation of BIM in the UK construction industry. Engineering, Construction, and Architectural Management, 19(6), 610-635. doi:10.1108/09699981211277531

Fellows, \& Liu. (2008). Research methods for construction (3rd ed.). Oxford: Wiley-Blackwell.

FMI. (2007). Eight Annual Survey of Owners.

Freeman. (2006). 'Best practice' in focus group research: making sense of different views. Journal of Advanced Nursing, 56(5), 491-497. doi:10.1111/j.1365-2648.2006.04043.x

Gould, F. E., \& Joyce, N. (2009). Construction project management (3rd ed.). Upper Saddle River, NJ: Pearson Prentice Hall.

Grbich, C. (2013). Qualitative Data Analysis - An Introduction. SAGE Publications Limited.

Guo, L., Li, H., Chan, G., \& Skitmore, M. (2012). Using game technologies to improve the safety of construction plant operations. Accident; Analysis and Prevention, 48, 204-213. doi:10.1016/j.aap.2011.06.002 PMID:22664683

Houssin, R., \& Coulibaly, A. (2011). An approach to solve contradiction problems for the safety integration in innovative design process. Computers in Industry, 62(4), 398-406. doi:10.1016/j.compind.2010.12.009

International Labour Office - Occupational Safety and Health Branch. (2014). A 5 step guide for employers, workers and their representatives on conducting workplace risk assessments.

International Organization for Standardization. (2009). ISO 31000 Risk Management - Principles and Guidelines.

Ju, C. R. S., \& Rowlinson, S. (2014). Institutional determinants of construction safety management strategies of contractors in Hong Kong. Construction Management and Economics, 32(7-8), 725-736. doi:10.1080/014 46193.2014.909048

Jung, Y., \& Joo, M. (2011). Building information modelling (BIM) framework for practical implementation. Automation in Construction, 20(2), 126-133. doi:10.1016/j.autcon.2010.09.010

Kam, C., Fischer, M., Rinella, T., Mak, D., \& Oldfield, J. (2014). Realising the Promise of BIM in Hong Kong's Construction Industry. Journal of Hong Kong's Construction Industry, (May), 29-33.

Kidd, P. S., \& Parshall, M. B. (2000). Getting the focus and the group: Enhancing analytical rigor in focus group research. Qualitative Health Research, 10(3), 293-308. doi:10.1177/104973200129118453 PMID:10947477

Kim, K., \& Teizer, J. (2014). Automatic design and planning of scaffolding systems using building information modeling. Advanced Engineering Informatics, 28(1), 66-80. doi:10.1016/j.aei.2013.12.002

Kiviniemi, M., Sulankivi, K., Kähkönen, K., Mäkelä, T., \& Merivirta, M. L. (2011). BIM-based safety management and communication for building construction. VTT research notes, 2597.

Ku, K., \& Taiebat, M. (2011). BIM Experiences and Expectations: The Constructors' Perspective. International Journal of Construction Education and Research, 7(3), 175-197. doi:10.1080/15578771.2010.544155

H.K.G. Labour Department. (2002). Code of Practice on Safety Management.

H.K.G. Labour Department. (2014). Occupational Safety and Health Statistics 2013.

Labour Department Hong Kong. (2000). Factories and Industrial Undertakings (Safety Management) Regulation. Retrieved from http://www.legislation.gov.hk/blis_ind.nsf/WebView?OpenAgent\&vwpg=CurAll EngDoc*59.31*0*59.31\#59.31

Labour Department Hong Kong Government. (2015). Occupational Safety and Health Statistics 2014.

Leedy, P. D., \& Ormrod, J. E. (2010). Practical research: planning and design (9th ed., international ed.). Upper Saddle River, NJ: Pearson Education International. 
Lingard, G., Graham, P., \& Smithers, G. (2000). Employee perceptions of the solid waste management system operating in a large Australian contracting organization: Implications for company policy implementation. Construction Management and Economics, 18(4), 383-393. doi:10.1080/01446190050024806

McGraw Hill Construction. (2014). The Business Value of BIM for Construction in Major Global Markets: How Contractors around the World are driving Innovation with Building Information Modeling.

McKinsey \& Company. (2015). Building for a better future Vision 2030 for the Hong Kong Construction Industry.

Miettinen, R., \& Paavola, S. (2014). Beyond the BIM utopia: Approaches to the development and implementation of building information modeling. Automation in Construction, 43, 84-91. doi:10.1016/j.autcon.2014.03.009

Mordue, \& Finch. (2014). BIM for construction health and safety. RIBA Publishing.

Morgan, D. (1993). Successful focus groups: advancing the state of the art. Newbury Park, CA: Sage Publications. doi:10.4135/9781483349008

Morgan, D. (2012). Focus groups and social interaction. In J. Gubrium (Ed.), The Sage handbook of interview research: The complexity of the craft (pp. 161-176). CA: Sage.

Neuendorf, K. A. (2002). The content analysis guidebook. Thousand Oaks, CA: Sage Publications.

New York City, U. (2013). Building Information Modeling Site Safety Submission Guidelines and Standards. BIM MANUAL.

Nicholas, J. (1989). Successful Project Management. J. of Systems Management, 40, 24-30.

Gu, N., \& London, K. (2010). Understanding and facilitating BIM adoption in the AEC industry. Automation in Construction, 19(8), 988-999. doi:10.1016/j.autcon.2010.09.002

Nisbet, N. (2012). COBie-UK-2012.

Rajendran, \& Clarke. (2011). Building Information Modeling: Safety Benefits \& Opportunities. Professional Safety, 56(10), 44-51.

Reutter, \& Ford. (1996). Perceptions of public health nursing: views from the field. Journal of Advanced Nursing, 24(1), 7-15. doi:10.1046/j.1365-2648.1996.01681.x

Royal Institute of British Architects. (2012). BIM Overlay to the RIBA Outline Plan of Work.

Royal Institute of British Architects Enterprises Limited. (2015). NBS National BIM Report 2015.

Sacks, P., Perlman, A., \& Barak, R. (2013). Construction safety training using immersive virtual reality. Construction Management and Economics, 31(9), 1005-1018. doi:10.1080/01446193.2013.828844

Sacks, R., \& Pikas, E. (2013). Building information modeling education for construction engineering and management. I: Industry requirements, state of the art, and gap analysis (Author abstract). Journal of Construction Engineering and Management, 139(11), 04013016. doi:10.1061/(ASCE)CO.1943-7862.0000759

Saunders, Landis, \& Mecca, Jones, Schaefer, \& Bilec. (2013). Analyzing the Practice of Life Cycle Assessment Focus on the Building Sector. Journal of Industrial Ecology, 17(5), 777-788. doi:10.1111/jiec.12028

Scott, H., Hofmeister, N., Rogness, N., \& Rogers, A. E. (2010). Implementing a fatigue countermeasures program for nurses: A focus group analysis. The Journal of Nursing Administration, 40(5), 233-240. doi:10.1097/ NNA.0b013e3181da4078 PMID:20431458

Shepherd, G. W., Kahler, R. J., \& Cross, J. (2000). Crane fatalities- A taxonomic analysis. Safety Science, 36(2), 83-93. doi:10.1016/S0925-7535(00)00017-5

Shin, I. (2015). Factors that affect safety of tower crane installation/dismantling in construction industry. Safety Science, 72, 379-390. doi:10.1016/j.ssci.2014.10.010

Sim, J. (1998). Collecting and analysing qualitative data: issues raised by the focus group. Journal of Advanced Nursing, 28(2), 345. 
Smith, D. K. T. Michael. (2009). Building information modeling: a strategic implementation guide for architects, engineers, constructors, and real estate asset managers. Hoboken, NJ: Wiley.

Standards Australia / Standards New Zealand. (2001). Occupational health and safety management systems: general guidelines on principles, systems and supporting techniques (2nd ed.). Sydney, Australia: Standards Australia Int'l Ltd.

Tam, C., \& Fung, I. W. (1998). Effectiveness of safety management strategies on safety performance in Hong Kong. Construction Management and Economics, 16(1), 49-55. doi:10.1080/014461998372583

Tam, C., \& Fung, I. W. (2011). Tower crane safety in the construction industry: A Hong Kong study. Safety Science, 49(2), 208-215. doi:10.1016/j.ssci.2010.08.001

Teo, E. A. L., \& Ling, F. Y. Y. (2006). Developing a model to measure the effectiveness of safety management systems of construction sites. Building and Environment, 41(11), 1584-1592.

Teo, M. M. M., \& Loosemore, M. (2001). A theory of waste behaviour in the construction industry. Construction Management and Economics, 19(7), 741-751. doi:10.1080/01446190110067037

Von Ahsen, A. (2014). The integration of quality, environmental and health and safety management by car manufacturers - A long-term empirical study. Business Strategy and the Environment, 23(6), 395-416. doi:10.1002/bse. 1791

Wan, A. (2017). The Application of Building Information Modelling for Safety in the Construction Industry [PhD Dissertation]. Leeds Beckett University.

Wan, A., Platten, A., \& Briggs, T. (2013). Study of Safety Auditors' Views on the Use of BIM for Safety in Hong Kong. International Journal of 3-D Information Modeling, 2(1).

Yu, S., Shen, Q., Kelly, J., \& Hunter, K. (2006). Investigation of critical success factors in construction project briefing by way of content analysis (Author abstract). Journal of Construction Engineering and Management, 132(11), 1178-1186. doi:10.1061/(ASCE)0733-9364(2006)132:11(1178)

Zhou, I., Irizarry, J., \& Li, Q. (2013). Applying advanced technology to improve safety management in the construction industry: A literature review. Construction Management and Economics, 31(6), 606-622. doi:10 $.1080 / 01446193.2013 .798423$

Dr. Allen Wan is a chartered HSEQ professional with over 20 years of combined industry and research experience, ranging from assisting chemical research in the US, running environmental testing laboratory in Canada, teaching HSEQ program \& implementing safety management system (SMS) \& audit in Hong Kong and researching Building Information Modelling (BIM) in the UK. Currently, Dr. Wan is a HSEQ manager for a lifting specialist in Hong Kong and Macau, with research interests of computing life cycle assessment for solid waste management, and adoption of BIM for environmental impact assessment, green building and SMS. 